\title{
The Islamic Call to Prayer and Its Origin: A Story about Cultural Memory's Permanence and Adaptability
}

\author{
Maroussia Bednarkiewicz
}

check for

updates

Citation: Bednarkiewicz, Maroussia 2021. The Islamic Call to Prayer and Its Origin: A Story about Cultural Memory's Permanence and Adaptability. Religions 12: 817. https://doi.org/10.3390/rel12100817

Academic Editor: Terry Lovat

Received: 30 July 2021

Accepted: 22 September 2021

Published: 28 September 2021

Publisher's Note: MDPI stays neutral with regard to jurisdictional claims in published maps and institutional affiliations.

Copyright: (C) 2021 by the author Licensee MDPI, Basel, Switzerland. This article is an open access article distributed under the terms and conditions of the Creative Commons Attribution (CC BY) license (https:// creativecommons.org/licenses/by/ $4.0 /)$
Faculty of Humanities, Eberhard Karls University of Tübingen, 72074 Tübingen, Germany; maroussia.bednarkiewicz@uni-tuebingen.de

Abstract: For more than two centuries, Muslims have been retelling different stories about the origin of their call to prayer. While the converging details of these narratives offer a glimpse of Muslim cultural memory and its preservation, the diverging elements reflect different mechanisms that facilitate the adaption of this cultural memory to new contexts and concerns. Based on the work of Jan Assmann, the present study explores how Muslims conserved and adapted their cultural memory to keep their common identity and expand their diversity following distinctive religious, political, or personal forms of belongings. The narratives concerned with the origin of the Islamic call to prayer and preserved in various written text collections offer a fertile ground to analyze how this part of Muslim cultural memory became the vehicle of a permanent but adaptable Muslim identity.

Keywords: Islamic history; cultural memory

\section{Introduction}

Hadith literature that preserves sayings and actions attributed to Islam's prophet Muhammad and his companions was formed over several generations in oral and written transmissions. Because its formative period stretched through great historical changes and radically different contexts, it often contains, in a single narrative, long-lasting old memories together with added comments, interpretations or modifications which reflect the transmitters' different times and concerns. It is therefore a rich source of information for the study of cultural memory, its permanence, and its malleability or ability to evolve. Memory, writes Jan Assmann, "is the faculty that enables us to form an awareness of selfhood (identity)" (Assmann 2013, p. 109): personal identities reside in individual memory, while cultural memory generates group identities. Cultural memory is therefore "[k]nowledge about the past [ ... ] if it is related to a concept of identity" (Assmann 2013, p. 113). The past is first remembered and transmitted from one generation to the next in what Assmann coined the "communicative memory" (the equivalent of Halbwachs' "collective memory," in Assmann's jargon). Communicative memory is short-term; it connects groups within two to three generations and gives a diffuse sense of community. When the past that is remembered is used to create a common identity ("awareness of selfhood") for a given community, it becomes this community's cultural memory (Assmann 2013, p. 114). A group, unlike an individual, does not have a brain that memorizes, explains Assmann. Groups store symbols and narratives in their cultures, and those who collectively remember these symbols and narratives acquire the group identity, in the sense that "remembering is a realization of belonging" (Assmann 2013, p. 114).

Cultural memory, because it preserves the group identity, must be preserved if the group is to survive, and for that it ought to be adaptable as time goes by and as new situations arise. But how can cultural memory be preserved and adapted the same time? How can collective identity survive in times of great disruptions that often require radical adaptations to new social, political and religious contexts? These questions can be explored in the light of a story that is found in the hadith literature. The narratives about the birth of the Islamic call to prayer, the adhān, exist in different versions within several hadith 
collections. All these narratives purportedly contain the account about the introduction of the adhān at the time of Muhammad. While the similarity between them could attest to the successful preservation of an old memory from the early Islamic history, their discrepancies reflect some attempts to interpret this old story anew and adapt it to different contexts or ideologies. The scope of this essay will not permit me to delve in the details of each of the numerous narratives, nor does it allow for a thorough contextualization or a large theoretical framework. This is why I shall build on the study I conducted in my doctoral dissertation and use Assmann's theory for its encompassing approach to the field of cultural memory, based on pioneers of cultural studies such as Maurice Halbwachs and Pierre Nora. As for the context, I will briefly highlight the broad contours of the period under consideration. I invite the reader to explore further these periods and themes through the secondary literature, bearing in mind that the adhān story is one example among many others.

\section{Context}

In the first half of the seventh century A.D., Medina is thought to have had a larger population of Jews and Christians than its southern neighbor, Mecca, the birthplace of Muhammad. The differences between these two places are in part reflected in the distinctive Meccan and Medinan chapters of the Qur'ān, which constitute important historical sources for this period and region. The Medinan verses can be distinguished through the numerous elements of distinction between Muslims on the one hand, and Jews and Christians on the other, such as the shift in the prayer direction from Jerusalem to Mecca (Q. 2:143-45), or a focus on Abraham as opposed to Jesus and Moses (Neuwirth 2007, p. 27). The adhān echoes this distinction process, yet it is not mentioned in the Qur'ān. The Arabic verb adhdhana, calling to prayer, from which are derived adhān, the call to prayer, and mu'adhdhin, the one who calls to prayer, appears in the Qur'ān, but does not refer to a ritual. The verb usually means "announcing," such as for example the herald (mu'adhdhin) of heaven and hell who announced (adhdhana) God's condemnation in sūra Al-A'rāf 7:44, or the herald (mu'adhdhin) who announced (adhdhana) to Joseph's brothers that one of them has stolen his cup in sūra Yūsuf Q. 12:77. The announcement can come from God, as in Q. 9:3, from God's messengers, as in Q. 22:27, or from simple people, as in the example of Joseph.

In the absence of references to the adhān in the Qur'ān, we are left with hadith narratives from later sources, which give only a blurred and incomplete picture of the historical development of the adhān. We also have little information about Medina's soundscape when Muhammad emigrated there in 622. The hadith literature establishes a parallel between animal horns or metal (silver) trumpets and the Jewish call to prayer. However, these instruments were not used to call to prayer. Rather they were parts of larger rituals within celebrations, such as Rosh Ha-Shanah (also known as yom teru'ah, the day of blowing), and played a symbolic role in reference to biblical events like Abraham's sacrifice, as I have shown in my doctoral dissertation (Bednarkiewicz 2017, p. 11). The idea of an instrument to call the believers to daily orations seems to come from the Christians, who struck a wooden board with a small wooden stick or a mallet, walking along the streets or within a monastery to indicate the time of their religious service. The instrument, called in Greek semantron, in Syriac nāqōsha, and in Arabic nāqu us, is first mentioned around the fourth or fifth centuries in written sources, but its exact origin remains unknown. The semantron was later replaced by bells when these were adopted by Christians but the Arabic language kept the same word to designate the semantron and its replacement, the bell (Rassi 2015, p. 268). This creates a confusion often visible in translations of early Arabic texts in which nnaqu $\bar{u}$ is translated as "bell," even though bells had not yet been introduced. The word semantron is sometimes translated as "clappers," which designate a smaller instrument that is the nāqūs/semantron to which our Arabic sources are referring. Hence, we shall keep the Arabic version of the Syriac word. The nāqus barely survived the introduction of bells, and it can only be found today among some Orthodox Christian communities on Mount Athos or in Jerusalem. These vestiges allow us nonetheless to gain an idea of the ritual as it was 
at the time of Muhammad, for deeply rooted traditions that survive the challenges of more efficient traditions do not get modified easily and often preserve old features. In the case of the semantron, complex and diverse rhythms have been identified in different monasteries, indicating a long history of distinction processes between Christian communities. Even if the tradition has changed, one can easily imagine when hearing the semantron today that this profound wooden sound with its surprising variations appeared attractive-and hence appropriate— to call the believers for a religious duty (al-Bayhaqi 1994, p. 574).

After the conquests, Muslims who mention the instrument are rather concerned with its nefast disturbance at the time of the adhān. Most jurists advocate the regulation of its use or its prohibition. In his record of Mālikī jurisprudences, the Tunisian jurist Sahnūn ibn Sa ${ }^{\prime} \bar{d}$ al-Tanūkhī (d. 240/854) reports that the famous Medinan jurist Mālik ibn Anas (d. 179/795) forbade the use of the nāqūs to Christians who had rented a house from a Muslim and were probably trying to circumvent the prohibition of building new churches by creating a private place of worship (Sahnūn b. Sa î̀ al-Tanūkhī 1906-7). A contemporary of Mālik, the Kufan jurist Sufyān al-Thawrī (d. c. 161/777) was said to have compared the sound of the nāqūs to the fart of a donkey (Abū Nu'aym al-Ișbahānī 1997, p. 379) and a student of Mālik, Muhammad ibn Idrīs al-Shāfi ì (2001, d. 204/820) recommended punishing the Christians who would strike their nāqūs. Abū Yūsuf Ya' qūb (d. 182/798) is a rare exception in this landscape, as he adopted a more lenient position by requesting that Christians should be allowed to perform their ritual except at the time of the adhān (Abū Yūsuf Ya'qūb 2009, p. 166). Abū Yūsuf's attempt to convince his audience that cultural diversity should be preserved to protect Muslim identity was dimmed by the hostility towards Christians that transpired inter alia in the jurists' writings cited above, as well as later ones (Rassi 2015; Bosanquet 2020, pp. 262-82). It is in this briefly summarized context and the following century that the narratives about the origin of the adhann were being circulated and recorded in hadith collections that were preserved until today. Astonishingly, the nāqu $\bar{s}$ appeared in almost all the accounts about this event and, as we shall see, it played a rather positive role in this story.

\section{The Origin of the Adhān}

\subsection{The Sources}

Three types of texts retell different versions of the history of the adhān as it was remembered by the Muslim communities. Most narratives come from the hadith literature, the collection of the accounts about the sayings and actions of Muhammad and his companions. All the famous canonical hadith collections report at least one and up to five versions of the story, ranging from almost identical to highly contradictory. Other non-canonical hadith collections also narrate the story adding a myriad of details to the already colorful narratives. In some accounts, Muslim historians approach the theme of the adhān and mention its history according to their own sources or interpretation thereof. Finally, some legal texts also introduce the story in a section dedicated to the adhān.

\subsection{The Nāqūs}

The main storyline of the Sunnī narratives goes as follows: someone suggests adopting the Christian $n \bar{a} q \bar{u} s$ to call the believers to the daily prayer, but the adhān is introduced instead. This seems to be the oldest layer of the narrative, the one that was circulated first, potentially within a larger narrative, the details of which are difficult to distinguish from the later additions or have been replaced by them. It is unlikely that the idea of adopting the $n \bar{a} q \bar{u} s$ and the early introduction of the $a d h \bar{a} n$ were invented after Muhammad's death for several reasons. Muslims after the conquests were trying to regulate, and in many cases forbid, Christian practices; in this context, Muslims were unlikely to invent a story in which a companion of their Prophet suggested striking the Christian $n \bar{a} q \bar{u} s$ to call Muslims to prayer. The disagreements between Muslims and Christians were already present during Muhammad's lifetime, as can be seen from the criticism against some Christian doctrines that appears in the Qur'ān, condemning the idea that Jesus was 
more than a messenger (Q. 4:171, 9:30-1, 19:36, 17:111 inter alia), or highlighting that most Christians went astray (Q. 5:66). These criticisms might have generated some tensions which were further accentuated by the conquests after Muhammad's death and the Christian resistance to Islam. The suggestion to use a $n \bar{a} q \bar{u} s$ could therefore only occur at a very early stage of Islam's development, in which the boundaries between Muslims and Christians, Islam and Christianity, were not fully erected and their permeability allowed for a certain osmosis (Donner 2010, pp. 56, 68). This formative period is reflected in the main storyline as well as in the Medinan verses of the Qur'ān, as mentioned above. With the hostility against Christians growing, one could have expected that the $n \bar{a} q \bar{u} s$ would be removed from the story about the genesis of the adhān, yet the contrary occurred: the $n \bar{a} q \bar{u} s$ was retained in most versions, even in those where the narrators clearly expressed a disagreement with or dislike of the fact that a Muslim companion was suggesting a Christian instrument, as will be shown below. The $n \bar{a} q \bar{u} s$ must have produced a powerful impression on the early Muslim community as it settled in Medina, and the idea of using the instrument for the Muslim call to prayer left its mark in Muslims' collective memory. The preservation of the $n \bar{a} q \bar{u} s$ underlines the permanent character of cultural memory: that which is collectively remembered cannot be erased easily if at all.

\subsection{The Early Adhān}

The second common element in Sunnī narratives is the early introduction of a specific Muslim call to prayer. How exactly this was introduced is an object of contention, but all texts agree that it came into being early on after the emigration to Medina. Tensions and disagreements within the Muslim community existed at the time of Muhammad, but they mostly gained prominence after his death, when the different factions chose different authority figures. This led to various splits, the most important of which being the division between the partisans of Muhammad's son-in-law 'Alī ibn Abī Tālib, and those of the first caliph Abū Bakr, and his two successors, 'Umar ibn al-Khatțāb and 'Uthmān ibn Affān. The former became the $S^{-} \overline{1} \overline{1}$ and distinguished themselves from the latter, the Sunnī, in part with their slightly distinctive call to prayer, in which a sentence is added referring to 'Alī: after the shahadah that attests the belief in God and his Prophet Muhammad, the Shī $\overline{1}$ add ashhadu anna 'alīyun walìyu-llāh ("I attest that 'Alī is the wali [guardian, regent] of God"). Shî̀ $1 \overline{1}$ sources also preserve, in their tradition, a different version of the story retelling the origin of the $a d h \bar{a} n$. They do not seem to be interested in why the $a d h \bar{a} n$ was introduced and whether the $n \bar{a} q \bar{u} s$ played a role there, but they stress the presence of 'Alī when the ritual was revealed to the Prophet Muhammad. The Shî̀ $\overline{1}$ adhān and the story of its origin point to an early dating of their initial forms, of which, however, we do not have historical traces: it transpires that the ritual and the narratives about its origin were sufficiently established as marker of the common Muslim identity to allow different Muslim factions to adopt and adapt them to distinguish themselves while remaining within the community. The Shî $\overline{1}^{-1}$ (or the proto-Shî $\overline{1}$, since we do not know when their adhān emerged) were not the only ones. The first caliphs after Muhammad's death were also reported to have added formulae to the adhān and to have tried to associate their names with the story of its origin (al-Maqrīzi 1998, vol. IV, p. 45 ss.) More tangible, however, is the preservation and adaptation of cultural memory through the medium of not only rituals, but also narratives. As we shall see, attempts to modify the narratives seem to have been as numerous and systematic as attempts to modify the ritual.

The adhān, or a proto-adhān, initially served the distinction between those who followed Muhammad and those who did not. Other common rituals indicate this early development phase of the Muslim community, formed the basis of the shared identity between all Muslim sub-communities and factions. Among them, we find the prayer, its purification ritual $(w u d \bar{u})$, some of its gestures (standing, bending, kneeling, but not the movement of the hands nor the daily number of prayers), and the pilgrimage. They became pillars of the Muslim common identity and, as Assmann has shown for rituals in general, their repetitions ensure identity transmission and cultural coherence (Assmann 2000, p. 89). 
The transfer of cultural memory from generation to generation also occurs through texts like the hadith narratives retelling the birth of the adhān. But texts are lost more easily than old rituals are forgotten. Therefore, texts are often remembered and transmitted in codified ways which resemble rituals to safeguard the identity information that they carry, and they are interpreted by recognised authorities (Assmann calls them "institutions of interpretation") to guarantee cultural coherence (Assmann 2000, p. 95). Like the imām who leads the prayer or the mu'adhdhin who calls to prayer, hadith authoritative figures played an important role in both preserving and adapting the texts that were entrusted to them (Davidson 2020, chps. 1 and 2). When the hadith canon had been established, their interpretations appear in the form of commentaries, but before the canonization, these interpretative comments seem to have been inserted directly in the texts, either orally or in written forms, and they might account for some discrepancies that occur between narratives supposedly retelling the same story. This is a phenomenon that can be observed in the story about the birth of the $a d h \bar{a} n$, and we shall now turn to the differences between its various versions.

\subsection{A Muslim Nāqūs?}

Among the disagreement comes first the exact role of the nāqus. While the sources agree that some Muslims suggested adopting the Christian instrument, they disagree about whether or not the instrument was actually used. The absence of clear temporal markers already renders the span of the story difficult to reconstruct: was the adhan introduced during a deliberation or over several months, maybe after the trials of different instruments? Was there a primitive form that slowly evolved into the ritual we know today? In some narratives, we have a conversation:

When Muslims arrived in Medina, they would gather and then complete the prayer, and no one would call them. One day they talked about it, some suggested to use a $n \bar{a} q \bar{u} s$ like the $n \bar{a} q \bar{u} s$ of the Christians, others said no, let us use the qarn like the qarn of the Jews, [but] 'Umar [ibn al-Khattāb] said, couldn't we send a man to call to prayer? And the Messenger of God [...] said: O Bilāl, stand up and call to the prayer. (Ibn Hanbal 1993, p. 399)

This dialogue must have lasted a couple of minutes, the instruments were suggested but not used, and a ritual with the voice, that is without instruments, was adopted at the end of the deliberation. In another version however,

[T] he Messenger of God [...] was worried that, when the time of [the prayer had come] he would make a $b \bar{u} q$ (trumpet) like the $b \bar{u} q$ of the Jews with which they call to their prayer, and he disliked that, then he ordered a $n \bar{a} q \bar{u} s$, and it was chiselled to be struck for Muslims for the prayer. (Ibn Hishām 1990, p. 150; Ibn Māja 2000, p. 103)

While the Prophet worries about this, a companion of his has a dream in which the adhān is revealed to him. He narrates it to Muhammad, who immediately adopts it. In this version the time span has increased, it stretches over some hours, maybe some days, to accommodate the chiseling of the instrument and the dream. In yet another, similar hadith, "Muhammad ordered the nāqūs (amar $\left.{ }^{a} b i-l-n \bar{a} q \bar{u} s\right)$ to be manufactured $\left(y u^{\prime} m a l^{u}\right)$ so that it could be stroked for the people [to announce] the common prayer" (Abū Dāwūd 2009, p. 371). Whether Muslims stroked the nāqūs or not, and the exact details of the original story will probably remain a mystery. However, the disagreement around this question makes it clear that the striking of the nāqus by Muslims was perceived differently by different transmitters. With the hostile attitude towards the instrument adopted by many jurists, who were often hadith transmitters themselves, the distance that some narratives underline between Muslims and the nāqūs is not surprising.

This distance is strengthened by the occasional presence of various Jewish instruments: $b \bar{u} q$ (metal trumpet), qarn (an animal's horn), and shabbūr (a shofar). The parallel between the Jewish and the Christian instruments, also reflected in the syntax of Ibn Hanbal's hadith 
mentioned above, dilutes the inspirational role of the $n \bar{a} q \bar{u} s$. Two narratives in the famous canonical collections of al-Bukhārī and Muslim even replaced the trumpet with a fire, which is a strange idea to call people to prayer, but gives the illusion that the $n \bar{a} q \bar{u} s$ was just a tool among others (al-Bukhārī 2000, vol. I, p. 119; Muslim 2006, p. 207). Finally, the nāqūs is often mentioned alone, and when all these different versions are compared, it appears that the particular role potentially played by the $n \bar{q} q \bar{u} s$ was problematic to more than one transmitter. This is confirmed by the next example.

\subsection{He Disliked the Nāqūs}

We find a minority of instances where a sentence has been added to indicate that Muhammad disliked (kariha) the idea of using a nāqūs (Ibn Hanbal 1993, p. 399; al-Dārimī 2014, p. 307; Ibn Māja 2000, p. 104; Ibn Sa'd 2001, p. 213). This sentence reflects the will to remove all doubts about Muslims having used a Christian instrument: the $n \bar{a} q \bar{u} s$ was suggested to Muhammad and directly rejected by him. Most likely, the addition of this sentence was understood as an authoritative interpretation of the intended meaning and not as a modification of the original text. This interpretation fits well in the hostile context described above, where jurists advocated the prohibition of the nāqus. The Prophet's dislike supports this view and the chosen verb kariha (he disliked) is close to "forbid" (harrama) in Islamic normative law, which provides the following scale: obligatory (wäjib), recommended or encouraged (mandīb), allowed or permitted (mubāh), disliked (makrūh), and forbidden, illicit or proscribed (mahzū liked" (makrūh) by the Prophet could vary among jurists from something being considered disapproved, controversial, questionable, or even (morally) reprehensible. An instrument qualified as makrūh will definitely not be used by Muslims.

There is one other example of an attempt to avoid confusion regarding Muslims use of a Christian instrument that was creatively introduced by Mālik ibn Anas, who preferred a synecdoche to the addition of a sentence. Indeed, he refers to "two pieces of wood" (khashbatayn) instead of the foreign word nāqūs (Mālik ibn Anās 1952-53). He succeeds in preserving the meaning while avoiding the explicit mention of the Christian instrument and removing therewith the clear reference to the Christian influence on the introduction of the adhān. Together with the addition of the Prophet's dislike, Mālik's solution confirms a certain uneasiness among Muslim transmitters around the 2nd/8th century about the $n \bar{a} q \bar{u} s$ and its role in the genesis of the adhān.

\subsection{The Adhān of 'Umar Ibn al-Khatțāb}

The disagreement about how the adhān was introduced concerns not only the $n \bar{a} q \bar{u} s$ but also the person who came with the idea of a different call to prayer using the voice instead of an instrument. In the narrative mentioned above, it was 'Umar ibn al-Khațāb who suggested calling the people to prayer. In his version of the story, Ibn Hanbal used the verb $n \bar{a} d a$ ' for "calling," and not adhdhana, which is the verb that came to describe specifically "performing the adhān." Thus, in Ibn Hanbal's hadith, 'Umar could have initiated the practice of calling to prayer with the voice (nāda'), which would have then evolved slowly into the more elaborate ritual we know today (adhdhana). In other versions of the same narrative with 'Umar as main protagonist, we find the two verbs, either as a mistake, a misinterpretation, or a will to associate the second caliph with the introduction of the adhan and not just a simple $n \bar{a} d a^{3}$.

\subsection{The Dream of 'Abd Allāh}

Another group of narratives replace 'Umar in his prominent role with 'Abd Allāh ibn Zayd, an anșāri or inhabitant of Medina who converted to Islam (in opposition to the muhājirīun, the companions of Muhammad who came with him from Mecca). 'Abd Allāh ibn Zayd had a dream in which he asked a man carrying a nāqūs to lend him his instrument to call Muslims to prayer, and the man, often dressed in green, taught him the wordings of the adhān. 'Abd Allāh narrated his dream to Muhammad, who recognized the vision as 
divinely inspired and asked Bilāl to call people to the prayer with the words from 'Abd Allāh's dream. 'Umar reappears in many narratives which recount that he had had the same dream as 'Abd Allāh. Whether the insistence on 'Umar is historically or politically motivated, is difficult to determine. The hadith in which 'Umar appears alone without the anșāri is narrated by his son, 'Abd Allāh ibn 'Umar, and his mawlá (freed slave), Nāfi', which could mean that, being close to 'Umar, they knew better what happened, or on the contrary, they had personal interest in promoting someone from their family, especially when he was criticized by his opponents during and after his caliphate. According to al-Maqrizi (d. 845/1442), an Egyptian historian from the 9th/15th century, 'Umar is the caliph who introduced into the adhān a sentence praising himself as the ruler: "Peace be upon you amīr al-mu'minīn and God's mercy and His blessing" (al-Maqrīzī 1998, p. 48) Many rulers after him are said to have used the adhān to have their name resonate daily in the soundscape of their city, since "[r]eligious noise was a powerful signal of territorial control" (Constable 2010, p. 93). The emphasis on "Umar, whether his role in the origin of the adhān was authentic or not, visibly associates him with the introduction of the ritual and indirectly entitles him to modify his own invention in order to protect him against criticism, similar to the narrative that justified 'Umar's prayer without the Qur'ān's verses (Sijpesteijn 2015, p. 326). The presence of an anșāri could also be politically motivated, for feelings of injustice are often reported from anșāri who complained about favors being bestowed upon the muhäjiriunn, at the time of Muhammad and after, in particular regarding those from Muhammad's tribe, the Quraysh. Some accounts of the history of the adhann allude to these feelings when they report how a person asked why a muhājir, Bilāl, was chosen to perform the adhān instead of the anșāri ' Abd Allāh ibn Zayd, who received divine inspiration (Abū Dāwūd 2009, p. 369; al-Bayhaqī 1994, p. 574; Abū Dāwūd al-Ṭayālisī 1999, vol. II, p. 425). Finally, one narrative seems to seek a middle ground by introducing as the first caliph Abu Bakr instead of 'Abd Allāh ibn Zayd, 'Umar, or 'Alī (?, p. 18 [85B4-religions-1342683). By associating the origin of the adhān with a particular figure, each transmitter preserved the main storyline, and was able to defend or enhance the figure he had chosen for political, personal, or religious reasons. The Shî'î narratives follow this strategy.

\subsection{The Shĩ $\bar{\imath}$ Traditions}

The veracity of 'Abd Allāh ibn Zayd al-Anșārī's dream was challenged by Al-Qāḍī al-Nu'mān (d. 363/974), chief judge of the fourteenth Ismā'îlī Imām and the fourth Fātimid caliph al-Mu'izz li-dīn Allāh (r. 341/953-365/975). According to him, the exact wording of the adhān was revealed to Muhammad by God through an angel (al-Qāẹī al-Nu'mān 2007, pp. 59-60). Around the same period, the famous twelver Shî̀̄ Ibn Bābawayh (d. 381/991-2) does not acknowledge any of the Sunnī narratives, and simply explains that the angel Jabrā'īl (Gabriel) revealed the adhān to Muhammad, who had his head on 'Alī's lap: they both heard the words, and Muhammad then taught Bilāl to perform the call accordingly (Ibn Bābawayh 1981, pp. 197-98). The two Shîî scholars do not comment on the ancestor of the adhān; whether Muslims used a nāqu $\bar{s}$ or not did not seem relevant to them. Their concern lies entirely with establishing the divine revelation to the Prophet by an angel similar to the revelation of the Qur'ān. Some Sunnī narratives also attempt to stress the divine origin of the adhān when they add that Muhammad recognized 'Abd Allāh's (and 'Umar's) dream as a revelation, $r u^{\prime} y a$, that is a dream inspired by God. The discrepancies between the narratives about the person from whom the $a d h \bar{a} n$ originated reflect rather early debates in Islamic history between anșāri and muhājirūun, Quraysh and non-Quraysh, and the first caliphs. The need to attribute the origin of the ritual exclusively to God and his Prophet likely reflects later concerns, when Muslims were no longer concerned about distinguishing themselves from Jews and Christians, and instead wanted to stress the divine nature of their rituals and the equal or superior status of their religion. The message behind this was that Muslims were not performing the adhān because the Christians were also calling the faithful to prayer or because a companion had a brilliant idea, but because God himself told his Prophet to do so. 


\section{Conclusive Remarks}

The foregoing discrepancies between the narratives about the origin of the adhān show how different groups within the Muslim community used a well-known story to advocate or stress particular points of interest, probably at different time in history: The supporters of the second caliph 'Umar ibn al-Khattā̄b could promote him while the anșāri had 'Abd Allāh ibn Zayd's dream, the twelver Shî̀ î insisted on 'Alī's presence beside the Prophet during the revelation of the $a d h \bar{a} n$ and those who felt the need to underline the sacred origin of the ritual emphasized its divine inspiration. Using the same foundational myth of origin and thus preserving their cultural memory, hadith transmitters kept reinterpreting the story, allowing different groups to claim their shared Muslim identity, while at the same time distinguishing themselves from other factions. Nowadays, each mu'adhdhin, mosque, or community might perform the adhān differently, and yet it remains a hallmark ritual, the $a d h \bar{a} n$, the Islamic call to prayer that has gathered all Muslims since the time of their Prophet, regardless of their divergences.

In this concert of voices, the historical truth might have been lost. We cannot establish who conceived the idea of a Muslim call to prayer using solely the voice, when it happened, who established its precise wording, and how it evolved. And yet, if the divergences obscure the historical origin, they preserve historical elements that were important for later generations; and because they are always attached to the same storyline, they shed light on the mechanisms of the adaptation and preservation of cultural memory. In his essay on the disappearance of rituals, the philosopher Byung-Chul Han observes, "rituals give rise to a resonance community, which is capable of a joint sound (Zusammenklang), a common rhythm" (Han 2019, p. 19 [my translation]). The adhān embodies this Zusammenklang which ties Muslims together regardless of their communitarian belonging and encapsulates both their collective identity and differences. None of the narratives introduce a radically different story, not only because the "past was not infinitely flexible" and could only "be reworked within certain boundaries" (Bowen Savant 2013, p. 168), but also because they participate in the preservation of this Zusammenklang. Through addition, modification, or reinterpretation of these narratives, Muslims could adapt their cultural memory to their new contexts and belongings. That narratives can be modified while retaining their essence make them a perfect vehicle for cultural memory as powerful as rituals and traditions. Investigating the hadith literature further under this light will surely yield a better understanding of the complex interplay between cultural preservation and diversification.

Funding: This research was funded by the Deutsche Forschungsgemeinschaft under Germany's Excellence Strategy-EXC number 2064/1-Project number 390727645.

Conflicts of Interest: The author declares no conflict of interest.

\section{References}

Abū Dāwūd, al-Sijistānī. 2009. Sunan. Edited by Shu'ayb al-Arna'ūṭ and Muhammad Kāmil Qarah Balilī. Damascus and Beirut: Dār al-risālah al-'ālamiyya, p. 369 ss.

Abū Dāwūd al-Ṭayālisī. 1999. Musnad. Edited by Muammad ibn 'Abd al-Muhasin al-Turkī. Egypt: Dār Hajar, vol II. p. 425 and vol. III, p. 567.

Abū Nu'aym al-Iṣbahānī. 1997. Hilyat al-awliyā’ wa-țabaqāt al-asfiyà'. Edited by Muștafá 'Abd al-Qādir. Beirut: Dār al-Kutub al- Ilmīyah, vol. VI, p. 379.

Abū Yūsuf Ya'qūb. 1976. Kitāb al-āthār. Edited by Abū al-Wafa' al-Afghanī. Beirut: Dār al-kutub al-'ilmīyah, p. 17 ss.

Abū Yūsuf Ya qūūb. 2009. Kitāb al-kharāj. Köln: Al-Kamel Verlag, p. 119 ss.

al-Bayhaqī̄, Aḥmad Ibn al-Ḥusayn. 1994. Al-Sunan Al-kubrá. Edited by Muammad 'Abd al-Qādir. Beirut: Dār al-kutub al- ilmīyah, p. 573 ss.

al-Bukhārī. 2000. Șah̄hh al-Bukhārī. 3 vols. Vaduz: Thesaurus Islamicus Foundation, I, p. 119 ss.

al-Dārimī. 2014. Kitā̄b al-Musnad al-jāmí. Edited by Nabīl ibn Hāshim al-Ghamirī. Beirut: Dār al-bashā'ir al-isālmiyyah, p. 307 ss.

al-Maqrīzī, Taqī al-Dīn. 1998. al-Mawā'iz wa-l-ítibār fì dhikr al-khițaṭ wa-l-āthār. Edited by Khalīl al-Manșūr. Beirut: Dār al-kutub al-ilmìyya, p. 45 ss.

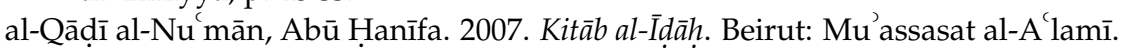

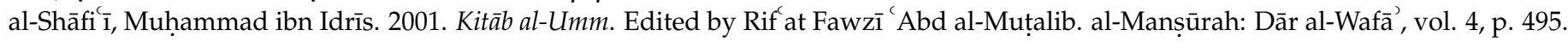


Assmann, Jan. 2000. Das kulturelle Gedächtnis. Schrift, Erinnerung und Politische Identität in frühen Hochkulturen. Munich: C.H. Beck.

Assmann, Jan. 2013. Communicative and Cultural Memory. In The Theoretical Foundations of Hungarian 'lieux de mémoire' Studies (Loci Memoriae Hungaricae 1). Edited by Pál S. Varga, Karl Katschthaler, Donald E. Morse and Miklós Takács. Debrecen: Debrecen University Press, pp. 36-43.

Bednarkiewicz, Maroussia. 2017. Summoning the Believers as the Christians did? Religious Differentiation in Muslim Sources until the Thrid/Ninth Century. Ph.D. dissertation, University of Oxford, Oxford, UK.

Bosanquet, Antonia. 2020. Minding Their Place: Space and Religious Hierarchy in Ibn al-Qayyim's Ahkām ahl al-dhimma. Leiden: Brill.

Bowen Savant, Sarah. 2013. The New Muslims of Post-Conquest Iran. Tradition, Memory and Conversion. Cambridge and New York: Cambridge University Press.

Constable, Olivia Remie. 2010. Regulating Religious Noise: The Council of Vienne, the Mosque Call and Muslim Pilgrimage in the Late Medieval Mediterranean World. Medieval Encounters 16: 65. [CrossRef]

Davidson, Garrett A. 2020. Carrying on the Tradition. A Social and Intellectual History of Hadith Transmission across a Thousand Years. Leiden: Brill.

Donner, Fred. 2010. Muhammad and the Believers. At the Origins of Islam. Cambridge: Harvard University Press.

Han, Byung-Chul. 2019. Vom Verschwinden der Rituale. Eine Topologie der Gegenwart. Berlin: Ullstein Buchverlage.

Ibn Bābawayh, Muammad ibn 'Alī al-Qummī. 1981. Kitāb man lā yahduruhu al-faqīh. Beirut: Dār Ṣa b.

Ibn Hanbal, Aḥmad. 1993. Musnad. Edited by Shu'ayb al-Arna' ūt. Beirut: Mu' assasat al-risālah.

Ibn Hishām. 1990. Al-Sīra al-nabawīya. Edited by 'Umar 'Abd al-Salām Tadmūrī. Beirut: Dār al-kitāb al-'arabī, vol. II, p. 149 ss.

Ibn Māja, Muhạmmad ibn Yazīd. 2000. Sunan Ibn Māja. Vaduz: Thesaurus Islamicus Foundation, p. 103 ss.

Ibn Sa 'd, Muhammad. 2001. Kitāb al-Ṭabaqāt al-kabīr. Edited by 'Alī Muhammad 'Umar. Cairo: Maktabat al-khānjī̄, p. 213 ss.

Mālik ibn Anās. 1952-53. al-Muwaț̣a’ . Edited by Muhammad Fu' ād 'Abd al-Bāqī. Cairo: p. 67.

Muslim. 2006. Al-Ṣaḥ̄ḥ. Edited by Abū al-Faḍl al-Damyātī. Cairo: Dār al-bayān al-arabīyah.

Neuwirth, Angelika. 2007. Studien zur Komposition der Mekkanischen Suren, 2nd ed. Berlin and New York: Walter de Gruyter.

Rassi, Salam. 2015. 'What Does the Clapper Say?': An Interfaith Discourse on the Christian Call to Prayer by 'Abdīshō' bar Brīkhā. In Islam and Christianity in Medieval Anatolia. Edited by Andrew C.S. Peacock, Bruno De Nicola and Sara Nur Yıldız. Farnham: Ashgate, pp. 263-84.

Sahnūn b. Sa ìd al-Tanūkhī. 1906-7. al-Mudawwana al-kubrā li'l-Imām Mālik b. Anas al-Asbahī. Riwwāyat Sahnūn b. Sa'īd al-Tanūkhī'an 'Abd al-Raḥmān b. al-Qāsim. Cairo: al-Maṭba'a al-Khayrīya, vol. IV, p. 518, (Reprint in 6 vols. Beirut: Dār Ṣādir, n.d).

Sijpesteijn, Petra M. 2015. A Hadīth Fragment on Papyrus. Der Islam 92: 321-31. [CrossRef] 